\title{
BRITISH FORCES CASUALTIES NORTHERN IRELAND
}

\author{
Colonel W. CAMERON MOFFAT, F.R.C.S., L/R.A.M.C.
}

Royal Army Medical College, Millbank

SUMMARY: This paper presents a broad view of the casualties occurring in British servicemen in Northern Ireland over a 4 year period 1 January 1971 to 31 December 1974. It is intended to serve as a backcloth against which more detailed reviews may be presented in the future but incidentally demonstrates the commendable efficiency of the Medical Services in Ulster, both Civil and Military.

The present troubles in Northern Ireland began in the autumn of 1969 with a series of large and alarming civil riots and the rumblings of organised terrorist activity. The small permanent troop garrisons stationed in the Province were augmented steadily in pace with the need to contain the mounting incidence of violence throughout the remainder of 1969 and in 1970 . There were many injuries to British soldiers during these years but they were largely occasioned by bricks and stones or bottles hurled by rioting mobs and there were few really serious injuries. Indeed until the end of December 1970 there were only 110 soldiers who required admission to hospital for an injury sustained on internal security duties and there were no deaths at all from that cause.

The shooting and bombing campaign began in earnest in 1971. Only then did serious injury and death start to occur. In December 1974 the Provisional IRA announced a cease-fire and since then until the time of writing military casualties have been few. For these reasons the present broad review of the casualties in British Forces in Northern Ireland is confined to the four year period 1 January 1971 to 31 December 1974. The available data have been processed in a fairly limited way and a few conclusions have been drawn but the facts and figures are recorded in the hope that they may formulate a useful background for further studies in the future. The figures have been obtained from a personal survey of actual case notes carried out on a number of occasions in the Military Wing of Musgrave Park Hospital and thus inaccuracies have been eliminated as far as possible.

In any consideration of British Forces casualties in Northern Ireland it should not be forgotten that a very large number were afforded their early treatment in Civil hospitals. Almost every hospital in the Province has been involved at some stage but particularly noteworthy, largely because of their proximity to the main areas of turbulence, are the Royal Victoria Hospital, Belfast and the Altnagelvin Hospital, Londonderry. The civil hospitals have on some occasions been called on to give initial surgical aid prior to evacuation but on others have undertaken the often heavy load of ongoing surgical care, particularly in cases calling for the special expertise in management available in the intensive care units for respiratory and neurological problems. The Military Wing at Musgrave Park Hospital was augmented in 1971 by the addition of considerable extra staff and equipment. Almost all casualties have been admitted there at some stage. Overall around 30 per cent have had all their treatment at the Wing. The remainder have been treated for varying periods in civil hospitals prior to admission there. It would 
not have been possible, throughout the period, to continue satisfactory working in the Military Wing without the expert evacuation service, both in and out, provided by the Royal Air Force (R.A.F.).

Table I shows the overall casualty figures in British Forces only during the four year

Table I

British forces casualties for the period 1971 to 1974

\begin{tabular}{c|c|c|c}
\hline Total casualties & Wounded & Dead & $\begin{array}{c}\text { Gross mortality } \\
\text { (percentage) }\end{array}$ \\
\hline 1357 & 1121 & 236 & 17.4 \\
\hline
\end{tabular}

period under review which came to the notice of the Army Medical Services (A.M.S.) by reason of hospital admission or death. In addition during that time 105 casualties in the Ulster Defence Regiments (U.D.R.) were notified and of these 58 were deaths and only 47 wounded. It is possible that many more were wounded but not notified to the A.M.S. However it is much more likely that the disproportionate number of deaths is accounted for by the fact that a considerable number of the dead were assassinated or murdered when off duty and those would not ordinarily be included in a review of military casualties. For these reasons the casualties occurring in U.D.R. troops have been excluded from this review which deals with the casualties occurring in British Forces only. Amongst these, and included in the overall totals, are 2 wounded and 24 deaths not directly attributable to injuries sustained on duty in security operations (Table VIII).

Figure I shows the distribution of deaths over the period. The number rose fairly

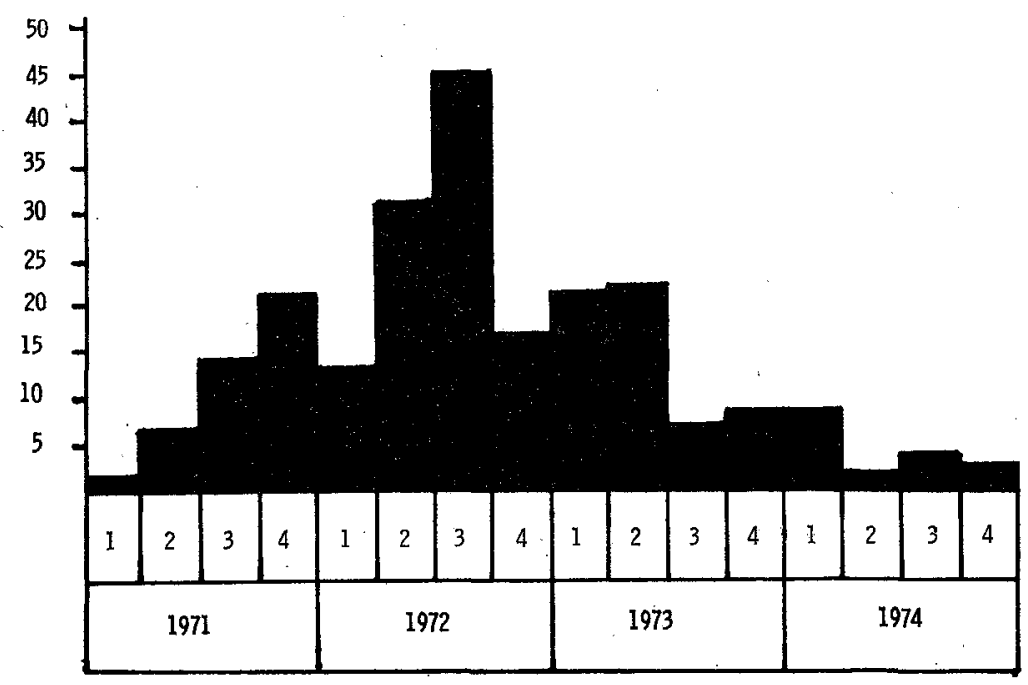

Fig. 1. British forces casualties 1971 to 1974 . Three monthly periods.

steadily until the third quarter of 1972 after which there was a sharp decrease probably in part at least due to the success of "Operation Motorman" when the "No-go" 
areas of Belfast and Londonderry were reoccupied and brought under surveillance by the Security Forces.

Table II shows the distribution of deaths by cause. It will be seen that of the 236

Table II

British forces casualties for the period 1971 to 1974

Cause of deaths

\begin{tabular}{|c|c|c|c|}
\hline Cause & Number & Total & Percentage \\
\hline $\begin{array}{l}\text { Explosive device } \\
\text { Bullet } \\
\text { Road traffic accident on duty }\end{array}$ & $\begin{array}{r}81 \\
135 \\
7\end{array}$ & 223 & $\begin{array}{r}36.3 \\
60.5 \\
3.2\end{array}$ \\
\hline $\begin{array}{l}\text { Road traffic accident off duty } \\
\text { Others }\end{array}$ & $\begin{array}{l}9 \\
4\end{array}$ & 13 & \\
\hline
\end{tabular}

deaths 13 were judged to be not attributable to internal security duties in Northern Ireland and incidental in the sense that they could as easily have occurred in England or Germany or other places. Nine were due to road accidents quite unconnected with duty journeys and 4 were from natural causes. About one third of the total deaths were due to explosive devices of all types. These included Booby Traps, Car Bombs, Land Mines, and a variety of others but so far it has not been possible to determine the proportion of deaths due to each type. Almost two thirds of the total dead were killed by bullets and this reflects the tactics employed for a good deal of the time in this particular campaign. Sniping at foot patrols or sharpshooting at soldiers drawn into an ambush " riot" has resulted in much death and injury. The proportion of those deaths due to injury with high velocity missiles is not known for certain but undoubtedly a large number of them were so caused.

Table III shows that the mortality from explosive devices was a little higher than

Table III

British forces casualties for the period 1971 to 1974

Overall mortality by weapon

\begin{tabular}{l|c|c|c}
\hline \multicolumn{1}{c|}{ Weapon } & Wounded & Dead & Percentage \\
\hline $\begin{array}{l}\text { Explosive device } \\
\text { Bullet }\end{array}$ & 262 & 81 & 23.6 \\
\hline
\end{tabular}

from bullet injury. Bullet hits accounted for 50.6 per cent of all casualties (694 of 1357) and 60.5 per cent of the deaths (135 of 223). Explosive devices caused 25 per cent of all casualties (343 of 1357) and 36.3 per cent of all deaths (81 of 223). Many of those who died as a result of an explosion were injured at very close quarters and sustained an injury immediately incompatible with life. Some bodies were recovered in pieces from a widely scattered area. Further study of this whole group will be worth while because of the number of incidents where men were wounded in proximity to others who were 
killed. In some of these incidents the amount and type of explosive is fairly accurately known, together with the distances involved and it may be possible to add to our knowledge on the observed effects of blast. Since, however, some of the explosives involved were of the " home-made" type employing fertilizer and other available chemical agents the value of such information as may be gained could be somewhat limited.

Table IV shows the proportion of wounded according to cause: The miscellaneous

Table IV

British forces casualties for the period 1971 to 1974

Cause of wound

\begin{tabular}{l|c|c}
\hline \multicolumn{1}{c|}{ Cause } & Number wounded & Percentage \\
\hline Explosive device & 262 & 23.3 \\
Bullet & 567 & 50.6 \\
Miscellaneous & 292 & 26.1 \\
\hline
\end{tabular}

causes include those from riot and road accident associated with riot or terrorist activity. Attention is again drawn to the high number wounded by bullets.

Tables V, VI and VII all refer to bullet hits. It should be noted that the figures for

Table $\mathrm{V}$

British forces casualties for the period 1971 to 1974

Mortality bullet wounds by region

\begin{tabular}{l|c|c|c}
\hline \multicolumn{1}{c|}{ Region } & Wounded & Dead & Percentage mortality \\
\hline Head & 41 & 46 & 53 \\
\hline Neck & 24 & 12 & 33 \\
\hline Chest & 70 & 48 & 47 \\
\hline Abdomen & 43 & 20 & 32 \\
\hline Limbs & 389 & 1 & .26 \\
\hline
\end{tabular}

Table VI

British forces casualties for the period 1971 to 1974

Combined percentage mortality bullet wounds by region

\begin{tabular}{l|c|c|c}
\hline \multicolumn{1}{c|}{ Region } & Wounded & Dead & Percentage \\
\hline Head and neck & 65 & 58 & 47.1 \\
\hline Head, neck and chest & 135 & 106 & 44.0 \\
\hline Head, neck, chest and abdomen & 178 & 126 & 41.4 \\
\hline Chest and abdomen (Trunk) & 113 & 68 & 37.6 \\
\hline All regions & 567 & 127 & 18.2 \\
\hline
\end{tabular}


Table VII

British forces casualties for the period 1971 to 1974

Region hit and target area (bullets only)

\begin{tabular}{l|c|c|c}
\hline \multicolumn{1}{c|}{ Region } & Total casualties & Percentage of total & Percentage of body area \\
\hline Head and neck & 123 & 17.7 & 12 \\
\hline Chest & 118 & 17.0 & 16 \\
\hline Abdomen & 63 & 9.1 & 11 \\
\hline Limbs & 390 & 56.2 & 61 \\
\hline
\end{tabular}

dead included all deaths and do not distinguish between those killed-in-action and those who died of wounds. The high mortality in association with head and truncal injury is in accordance with expectation based on past wars and campaigns. The mortality associated with bullet wounds of the limbs is very low. The implications in respect of head and body armour are clear, although it is not suggested that such forms of protection will defeat high velocity bullets. Table VII shows the effect of accurate aimed rifle fire in that 17.7 per cent of bullet hits were in the head and neck which represent only 12 per cent of body area although some of the discrepancy is accounted for otherwise as described below.

The figures shown in Table VIII demonstrate to some extent in a numerical way the

Table VIII

British forces casualties for the period 1971 to 1974

On duty casualties

\begin{tabular}{l|c|c|c}
\hline \multicolumn{1}{c|}{ Casualty } & Number & Percentage & Ratio \\
\hline Total & 1331 & & \\
\hline Wounded & 1119 & & \\
\hline Dead & 212 & & \\
\hline Overall mortality & & 16 & \\
\hline Brought in dead & 148 & & \\
\hline Died of wounds & 64 & & \\
\hline Percentage died of wounds & & 5.7 & $1: 9$ \\
\hline Ratio Killed in action/admitted wounded & & & \\
\hline Overall survival & & 84 & \\
\hline
\end{tabular}

efficiency of the medical services afforded the British serviceman in Northern Ireland.

As previously pointed out there were 2 wounded and 24 deaths not directly attributable to injuries sustained on duty in security operations. 13 deaths were incidental (Table II) and a further 11 deaths occurred in soldiers who were off duty and who were 
murdered, usually by shooting in the head, and left in some remote place. These 24 deaths may legitimately be excluded from an assessment of security operation mortality figures looked at in terms of medical efficiency. One hundred and forty-eight casualties were dead before arrival at any medical aid (BID) and 1183 were admitted wounded. Thus 9 men were admitted wounded for every one who was dead prior to medical aid. This ratio is higher than for any other recorded campaign (Korea 1:3, Vietnam 1:4.15) and means that many of those admitted had sustained injuries which would have resulted in death in other campaigns. In spite of this only 64 died of wounds and thus the mortality of the wounded was 5.7 per cent. In comparison with other campaigns this might appear to be high (World War II 4.5 per cent; Vietnam 2.1 per cent) but for the reasons explained above it is in fact commendably low. The overall survival figure of 84 per cent is extremely high and reflects great credit on all those concerned with the management of casualties.

It should be pointed out again that the Army owes an inestimable debt to the Civilian Medical Services in Northern Ireland. Not only to doctors and nurses but to all workers in hospitals throughout the Province and to the Police, Fire and Ambulance Services all of whom gave of their best at a time when they were sorely tried in other directions. Those members of the Army Medical Services and the Royal Air Force Medical Evacuation teams, who served in Ulster can reasonably feel content with their efforts in support of the British Forces in a difficult situation.

\section{Queen's Honorary Surgeon}

Colonel (Acting Brigadier) C. D. Sanders, L.M.S.S.A., D.A., F.F.A.R.C.S., late R.A.M.C. is appointed Honorary Surgeon to The Queen, with effect from 26 September 1975, in succession to Major-General J. Irvine, O.B.E., Ch.B., p.s.c.

\section{COLONEL COMMANDANT R.A.M.C.}

Major-General T. W. Carrick, O.B.E., M.B., Ch.B., F.F.C.M., D.P.H., D.I.H., late Royal Army Medical Corps, has been appointed a Colonel Commandant R.A.M.C., with effect from 19.July 1975. 